\title{
The Influence of Mastery Motivation Towards Social- Emotional Competence in Early Childhood
}

\author{
Anayanti Rahmawati ${ }^{1}$, Mareyke Maritje Wagey Tairas ${ }^{2}$, Nur Ainy Fardana Nawangsari ${ }^{3}$ \\ Pendidikan Guru Pendidikan Anak Usia Dini, Universitas Sebelas Maret, Surakarta(1) \\ Psikologi, Universitas Airlangga, Surabaya ${ }^{(2,3)}$ \\ DOI: $10.31004 /$ obsesi.v5i2.1008
}

\begin{abstract}
Establishing interpersonal relationships is an important task of early childhood. Harmonious interpersonal relationships will be achieved well if children have social-emotional competence, namely the ability to manage their own condition in order to maintain positive relationships with others. This study aims to determine the influence of mastery motivation towards socialemotional competence. This type of research is quantitative. The total sample was 417 children aged 5-6 years. Collecting data using a questionnaire filled out by teachers and parents. Data analysis using linear regression method with t-test obtained $t$ test results of 3.776 and sig of 0.000 . Based on these results, it can be concluded that there is an influence of mastery motivation towards social-emotional competence. The magnitude of the influence of mastery motivation was $3.3 \%$. Taking into account the effect of mastery motivation on low social-emotional competence, it is hoped that teachers and parents can foster mastery motivation so that socialemotional competence can be achieved more optimally.
\end{abstract}

Keywords: mastery motivation; social-emotional competence; early childhood

\begin{abstract}
Abstrak
Menjalin hubungan interpersonal merupakan tugas penting anak usia dini. Hubungan interpersonal yang selaras akan dapat tercapai dengan baik jika anak-anak memiliki kompetensi social-emosional yaitu kemampuan untuk mengelola kondisi diri sendiri guna mempertahankan hubungan positif dengan orang lain. Penelitian ini bertujuan untuk mengetahui pengaruh mastery motivation terhadap kompetensi social-emosional. Jenis penelitian adalah kuantitatif. Jumlah sampel sebanyak 417 anak yang berusia 5-6 tahun. Pengumpulan data menggunakan kuesioner yang diisi oleh guru dan orangtua. Analisis data menggunakan metode regresi linier dengan uji-t diperoleh hasil uji t sebesar 3.776 serta sig sebesar 0.000. Berdasarkan hasil tersebut dapat disimpulkan terdapat pengaruh mastery motivation terhadap kompetensi social-emosional. Besarnya pengaruh mastery motivation sebesar 3,3\%. Memperhatikan pengaruh mastery motivation terhadap kompetensi socialemosional yang masih rendah sangat diharapkan bagi guru dan orangtua untuk dapat menumbuhkan mastery motivation agar kompetensi social-emosional dapat teraih lebih optimal.
\end{abstract}

Kata Kunci: mastery motivation; kompetensi social-emosional; anak usia dini

Copyright (c) 2021 Anayanti Rahmawati, Mareyke Maritje Wagey Tairas, Nur Ainy Fardana Nawangsari

$\triangle$ Corresponding author :

Email Address : anayanti_r @staff.uns.ac.id (Slamet Riyadi Street No. 449, Surakarta)

Received 28 December 2020, Accepted 12 January 2021, Published 20 January 2021 


\section{INTRODUCTION}

Early childhood has various development tasks. One of the most important developmental tasks in the social emotional field is the ability to build relationships with others. Establishing interpersonal relationships is not an easy matter, it takes social-emotional competence, namely the ability to manage one's own condition in order to maintain positive relationships with others (Rahmawati, 2020). There are two main developmental tasks for children in establishing relationships, the first is maintaining positive engagement and the second is managing emotional conditions.

Social-emotional competence in detail consists of social competence and emotional competence. Orpinas (2010) states social competence is the ability to interact effectively. Ma (2012) further explains that social competence is often associated with children's ability to establish interpersonal relationships, especially in managing positive relationships and how to resolve conflicts. Another opinion was expressed by Hukkelberg et al (2019) which states that social competence is the ability to place oneself based on other people's points of view and apply it in the social situations it faces. This condition means that social competence is closely related to children's awareness of their sensitivity to the needs of others. Social competence is also useful for establishing communication and interpersonal relationships with people around the child.

Emotional competence is the ability to understand and respond effectively to the emotions of oneself and others (Gullone et al, 2010). Franco et al (2017) further explain that emotional competence includes the ability to express, identify, understand and regulate emotions. All of these emotional abilities need to be possessed by children, but the most important thing is emotional regulation (Santrock, 2013). Kim and Cicchetti (2010) explain that emotional regulation is a regulation of emotions that is closely related to individual involvement in initiating, motivating, regulating adaptive behavior and preventing negative emotions. Herndon et al (2013) adds that emotional regulation functions as a control system for emotions felt by children. The emotions felt by children can actually be expressed immediately, but if these emotions are processed first through emotional regulation, emotional expressions will emerge that are more in line with the expectations of the environment around the child. The suitability of emotional expression with the environment is needed so that children can be accepted by their social environment (Denham et al, 2012).

The development of social-emotional competence requires support and motivation from one's environment. The child's internal motivation is known as mastery motivation. Morgan et al (2014) stated that mastery motivation a psychological drive that stimulate individuals to concentrate and preserve, solve problems, or to master a skill or task. Mastery motivation will help children to overcome tasks that have not been conquered even without an external reward. The mastery motivation for the children is diverse and covers many contexts and areas, but those related to social-emotional development consist of three dimensions, namely social persistence with peers, social persistence with adults and mastery pleasure (Józsa et al, 2017).

Józsa et al (2017) explained that the dimensions of social persistence with peers and adults are internal drive in children to establish interpersonal relationships with peers and adults around them. The child's internal encouragement includes initiates, continues, and shapes social interactions, which are individual internal impulses without force or pressure (Morgan et al, 2014). A strong desire to be able to establish good interpersonal relationships with the people around them makes children try to adjust to the conditions of the environment around them. Children's self-adjustment will only be successful if it is supported by social emotional competence. In this condition, the role of mastery motivation is to encourage children to hone their social emotional competences for the better. Children who have succeeded in establishing good interpersonal relationships will get an extraordinary sense of joy, more than if they get rewards in any form. This expression of joy is a reflection of the 
mastery pleasure dimension, which can be expressed through smiling, laughing, or positive behavioral indicators during or after completing a task.

The descriptions that have been described show a correlation between mastery motivation and social-emotional competence. Mastery motivation will encourage children to initiates, continues, and shapes social interactions with the people around them without force. Mastery motivation will also encourage children to independently try to concentrate and diligently master social-emotional competencies, because this competence is the key to building good interpersonal relationships. Noting the important role of mastery motivation in the achievement of social-emotional competence, this study aims to determine the influence of mastery motivation towards social-emotional competence.

\section{METHODS}

The research method used is quantitative, with the aim of knowing the influence of the independent variable towards the dependent variable (Sugiyono, 2009). The independent variable is mastery motivation and the dependent variable is social-emotional competence. The influence of mastery motivation towards social-emotional competence can be seen in figure 1.
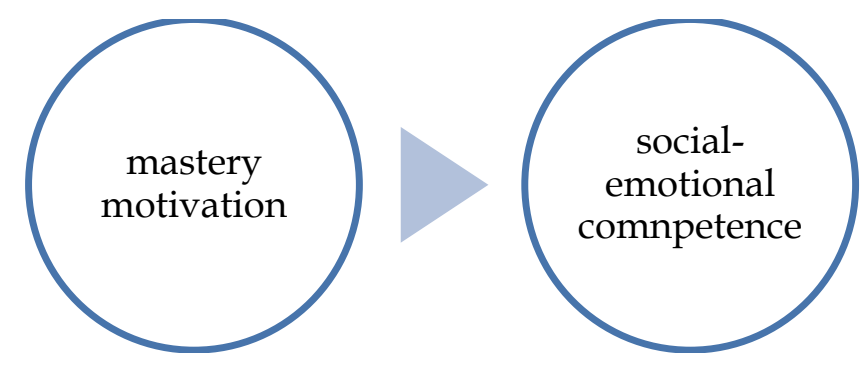

Figure 1. The Influence of Mastery Motivation towards Social-Emotional Competence

Data collection techniques using a Likert scale. Mastery motivation data is obtained based on the mother's assessment using a mastery motivation scale which is an adaptation of the Dimensions of Mastery Questionnaire (DMQ 18) compiled by (Józsa \& Morgan, 2015). The assessment of mastery motivation includes the efforts and persistence of the child in building interpersonal relationships with peers and adults as well as the expressions that the child feels during the process of trying to build interpersonal relationships with peers and adults.

Social-emotional competence data were obtained based on teacher assessment using the social competence scale and emotional competence scale. Social competence data is obtained using social competence scale which is an adaptation of the Penn Interactive Peer Play Scale (PIPPS) developed by McWayne at al (2002). Assessment of social competence includes the behavior shown by children when engaging in games together with peers, both positive and negative behavior (aggressive, anti-social, withdrawal). Emotional competence data were obtained using an emotional competence scale which was the result of an adaptation of the Emotion Regulation Checklist (ERC) compiled by Novitasari and Cicchetti (2015). Emotional competence assessment includes the child's ability to manage emotions and moods and regulate emotions according to the situations and conditions expected from their environment.

Data analysis used linear regression method with t-test statistics, using the SPSS program (Statistical Package for Social Sciences) version 23.

\section{Population and Sample}

The research was conducted in Sukoharjo Regency, Central Java Province. The study population included all kindergarten children aged 5-6 years. Sukoharjo Regency consists of 12 districts, with total of 564 kindergartens. Taking into account the size of the area and the 
large number of kindergartens available, the sampling is done by using multiple random sampling technique. The sampling flow can be seen in the figure 2 .

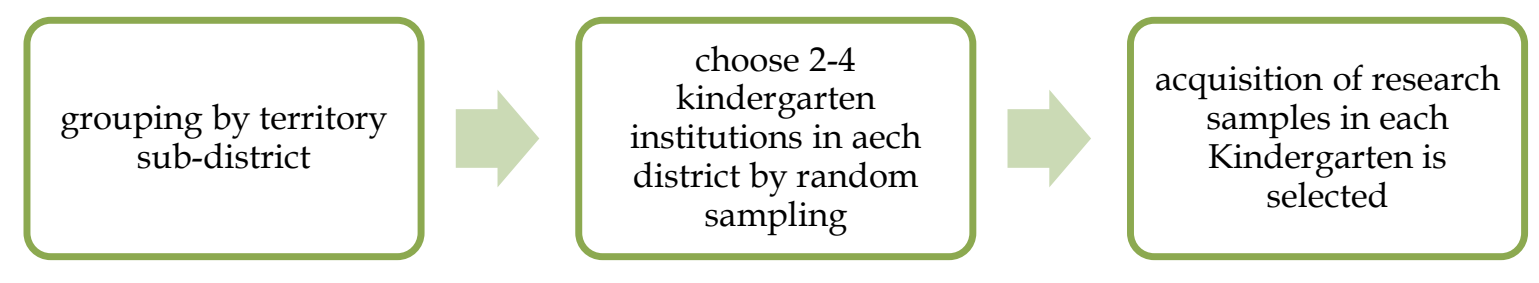

Figure 2. Flow of Multistage Random Sampling Technique

Based on the Figure 2, sampling is carried out with the following procedure: First, classify Sukoharjo regency based on 12 districts. Second, selecting kindergarten institutions by random sampling in each district as many as $2-4$ institutions. The results obtained were 28 kindergartens used for research. Third, determining the research sample according to the criteria, with the results of 417 children consisting of 211 males and 206 female children.

\section{RESULTS AND DISCUSSION}

The influence of mastery motivation towards social-emotional competence can be seen through hypothesis testing. The hypothesis is a provisional assumption based on the formulation of the problem, so that testing is necessary to find out the truth. The hypothesis of this research consists of H0, namely there is no influence of mastery motivation towards social-emotional competence and $\mathrm{H} 1$, namely there is an influence of mastery motivation towards social-emotional competence. The basis for the hypothesis decision is that if the value of Sig $>0.05$ then H0 is accepted, on the contrary, if the value of Sig $<0.05$, then $\mathrm{H} 0$ is rejected. The results of calculating the research hypothesis can be seen in Table 1.

Table 1. Hypothesis Test Results

\begin{tabular}{|c|c|c|c|c|c|c|}
\hline \multirow{2}{*}{\multicolumn{2}{|c|}{ Model }} & \multicolumn{2}{|c|}{$\begin{array}{l}\text { Unstandardized } \\
\text { Coefficients }\end{array}$} & \multirow{2}{*}{$\begin{array}{l}\text { Standardized } \\
\text { Coefficients } \\
\text { Beta }\end{array}$} & \multirow[t]{2}{*}{$T$} & \multirow[t]{2}{*}{ Sig } \\
\hline & & B & $\begin{array}{l}\text { Std. } \\
\text { Error }\end{array}$ & & & \\
\hline \multirow[t]{2}{*}{1} & (Constant) & -6.479 & 2.758 & & -2.349 & .019 \\
\hline & $\begin{array}{l}\text { Mastery } \\
\text { motivation }\end{array}$ & 235 & .062 & .182 & 3.776 & .000 \\
\hline
\end{tabular}

a. Dependent Variable: Social-Emotonal Competence

Based on table 1, it is known that the Sig value is 0.000 which means $<0.05$, then $\mathrm{H} 0$ is rejected so that $\mathrm{H} 1$ is accepted. This result means that there is an influence of mastery motivation towards social-emotional competence. After the hypothesis is proven correct, the next data analysis is knowing the value of the coefficient of determination ( $\mathrm{R}$ Square). The coefficient of determination is used to determine the magnitude of the influence that mastery motivation has on social-emotional competence. The results of calculating the coefficient of determination can be seen in table 2 .

Table 2. Determination Coefficient Test Results Model Summary

\begin{tabular}{|c|c|c|c|c|c|}
\hline Model & $\mathrm{R}$ & R Square & $\begin{array}{l}\text { Adjusted } \\
\text { Square }\end{array}$ & $\mathrm{R}$ & $\begin{array}{l}\text { Std. Error of the } \\
\text { Estimate }\end{array}$ \\
\hline 1 & $.182^{\mathrm{a}}$ & .033 & .031 & & 7.38087 \\
\hline
\end{tabular}

a. Predictors: (Constant), Mastery Motivation 
Based on table 2, it is known that the R square value is 0.033 . This value indicates the contribution of mastery motivation on social-emotional competence by $3.3 \%$. This means that the influence of mastery motivation on social-emotional competence is $3.3 \%$, while the remaining $96.7 \%$ is influenced by conditions other than mastery motivation.

Analysis of the research data shows that mastery motivation has an effect on socialemotional competence in children aged 5-6 years. This result is in line with the findings in Wise (2007) study which states that mastery motivation affects the achievement of socialemotional competence in children. The research findings of MacPhee et al (2018) also state that social-emotional competence in children is influenced by mastery motivation. Based on the results of these studies, it can be understood that social-emotional competence in children is influenced by mastery motivation, which is an internal drive from within the child himself, without interference from others.

Mastery motivation is internal encouragement from within the child, which leads to mastering tasks so that the child becomes competent. Wang et al (2011) based on the results of their research stated that there is a stability of mastery motivation in infancy and toddlerhood. Huang and Lay (2017) also state that mastery motivation from infancy to early childhood tends to be stable. This condition means that mastery motivation that has been formed in children will greatly affect the achievement of children's competence. Igoe et al (2011) stated that internal drive for mastery motivation is very supportive of achieving the competencies needed by children. Józsa (2018) emphasize that social-emotional competence in children can be achieved if supported by mastery motivation.

Children who have mastery motivation will have a strong desire and determination without any desire to get external rewards for mastering social-emotional competences. This condition can occur because the children's social-emotional competence is seen as a form of challenging task. Morgan et al (2014) explained that a task that is quite challenging for children is a task that is easy enough to show the level of success but quite difficult to complete in a short time. Challenging tasks will raise children's mastery motivation, thus encouraging children to try to complete them optimally.

Considering the low influence of mastery motivation on social-emotional competence, in previous research (Wise, 2007; MacPhee et al, 2018) is not explained further. The finding of the low influence of mastery motivation on social-emotional competence in this study indicates that the children's motivation to master social-emotional competence is still dominated by the influence of external conditions. External conditions that affect mastery motivation come from significant people around the child. The low mastery motivation is probably due to the fact that children are often helped by adults around the children when doing tasks. The assistance that the child gets during doing tasks makes the child dependent on others and weakens the spirit to be persistent in trying independently.

Research on mastery motivation in early childhood in Indonesia is still rare. The results of this study add to new findings about the condition of mastery motivation in children in Indonesia. Basically, mastery motivation already belonged to the children in the sample of this study, but it was still at a low level. The children in the sample of this study already have mastery motivation, which is the urge to try persistently and focus on mastering socialemotional competences without expecting any external reward.

Taking into account the results of this study, the role of involvement and guidance of important people around the child are needed so that children's mastery motivation can increase. Keilty and Freund (2004) stated that the best support for generating mastery motivation comes from parents. The results of previous research conducted by Turner and Johnson (2003) and Wise (2007) stated that parents as the closest children of children can stimulate them so that children have mastery motivation through parenting. Parents can encourage children to keep trying and trying things and emphasize not to fear failure. The need to foster a sense of optimism in children also plays an important role so that children are encouraged to dare to try. 
Increasing mastery motivation can also be done by teachers at school, through strengthening children's character. Teachers in schools are strongly advised to give appreciation when the child has successfully done an assignment. Giving appreciation will foster a child's self confidence, so that the child has the confidence that I can. The belief that is formed in children is expected to crystallize and become the character I can be. The next condition is that it is hoped that the children will be motivated to carry out activities diligently and earnestly even without any appreciation, so that a good mastery motivation is formed. Intensive guidance from teachers and parents is expected to increase children's mastery motivation. The hope is, when mastery motivation increases, social-emotional competence will also increase.

\section{CONCLUSION}

This study found that there is an influences of mastery motivation towards socialemotional competence in early childhood. The influence of mastery motivation on socialemotional competence is still low. This condition indicates that social-emotional competence still gets the main influence from external conditions, especially from significant people around children. Therefore, the role of teachers and parents is needed in guiding children so that children's mastery motivation can be improved. Further research is expected to further explore the influence of external factors towards social-emotional competence.

\section{ACKNOWLEDGEMENT}

The author would like to thank all those who have helped both materially and nonmaterially in completing this research. Especially for school principals, teachers, parents of children where this research was conducted, in Sukoharjo Regency, Central Java Province.

\section{REFERENCES}

Denham, S. A., Zinsser, K., \& Brown, C. A. (2012). The social emotional basis of learning and development in early childhood education. ( handbook of research on the education of young Children, Ed.) (3rd ed.). New York: Routledge.

Franco, M.G, Beja, M.J, Candeias, A., \& Natalie, S. (2017). Emotion Understanding, Social Competence and School Achievement in Children from Primary School in Portugal. Frontiers in Psychology, 8, 1-15. https:// doi.org/https:// doi.org/10.3389/fpsyg.2017.01376

Gullone, E., Hughes, E.K., King, N.J., \& Tonge, B. (2010). The normative development of emotion regulation strategy use in children and adolescents: a 2-year follow-up study. Journal Child Psychology Psychiatry, 51 (5), 74-567. https:// doi.org/http:/ / dx.doi.org/10.1111/j.1469-7610.2009.02183.x.

Herndon, K.J., Bailey, C.S., Shewark, E.A., Denham, S.A., \& Bassett, H. H. (2013). Preschoolers' emotion expression and regulation: Relations with school adjustment. The Journal of Genetic Psychology: Research and Theory on Human Development, 174 (6), 642-663. https:// doi.org/http://dx.doi.org/10.1080/00221325.2012.759525

Huang, S. \& Lay, K. (2017). Mastery motivation in infancy and early childhood: The consistency and variation of its stability and predictability of general competence. Hungarian Educational Research Journal, 7(2), 15-31. https:// doi.org/http://dx.doi.org/10.14413/HERJ/7/2/2.

Hukkelberg, S., Keles, S., Ogden, T., \& Hammerstrøm, K. (2019). The relation between behavioral problems and social competence: A correlational meta-analysis. BMC Psychiatry, 19 (354), 1-14. https:// doi.org/https://doi.org/10.1186/s12888-019-2343

Igoe, D., Peralta, C., Jean, L., Vo, S., Yep, L.N., Zabjek, K. \& Wright, F. V. (2011). A pilot evaluation of the test-retest score reliability of the dimensions of mastery questionnaire in preschool-aged children. Infants \& Young Children., 24 (3), 280-291. 
DOI: $10.31004 /$ obsesi.v5i2.1008

Józsa, K., \& Morgan, G. A. (2015). An improved measure of mastery motivation; Reliability and validity of the Dimensions of Mastery Questionnaire (DMQ 18) for preschool children. Hungarian Educational Research Journal, 5(4), 1-22.

Józsa, K., Barrett, K.C. \& Morgan, G. A. (2017). Game-like tablet assessment of approaches to learning: assessing mastery motivation and executive functions. Electronic Journal of Research in Educational Psychology, 15(3), 665-695. https://doi.org/http://dx.doi.org/10.14204/ejrep.43.17026.

Józsa, K., Barrett, K. . (2018). Affective and social mastery motivation in preschool as predictors of early school success: A longitudinal study. Early Child. Res. Q, 45 (4), 81-92.

Keilty, B., \& Freund, M. (2004). Mastery motivation: A framework for considering the how of infant and toddler learning. Young Exceptional Children, 8(1), 2-10. https://doi.org/https://doi.org/10.1177/109625060400800101.

Kim, J., \& Cicchetti, D. (2010). Longitudinal pathways linking child maltreatment, emotion regulation, peer relations, and psychopathology. Journal of Child Psychology and Psychiatry, 51(6), 706-716. https://doi.org/http://doi.org/10.1111/j.14697610.2009.02202.x.

Ma, H. K. (2012). Social competence as a positive youth development construct: A conceptual review. The Scientific World Journal, 3, 1-7. https://doi.org/http://doi.org/10.1100/2012/287472.

MacPhee, D., Prendergast, S., Albrecht, E., Walker, A. K., \& Miller-Heyl, J. (2018). The childrearing environment and children's mastery motivation as contributors to school readiness. Journal of Applied Developmental Psychology, 56, 1-12. https://doi.org/https://doi.org/10.1016/j.appdev.2018.01.002.

McWayne, C., Sekino, V., Hampton, G., \& Fantuzzo, J. (2002). Manual: Penn Interactive Peer Play Scale. Teacher and parent rating scales for preschool and kindergarten children. Philadelphia: University of Pennsylvania.

Morgan, G.A., Busch-Rossnagel, N.A., Barrett, K.C. \& Wang, J. (2014). The Dimensions of Mastery Questionnaire (DMQ 17): A manual about its development, psychometrics, and use.

Novitasari, H., \& Cicchetti, D. (2015). Emotional regulation checklist. Indonesian version (laporan penelitian tidak dipublikasikan). Surabaya: Universitas Airlangga.

Orpinas, P. (2010). Social competence. The Corsini Encyclopedia of Psychology. (I. Weiner, I.B. \& Craighead, W.E. WILEY. John Wiley \& Sons, Ed.) (4th ed.).

Rahmawati, A. (2020). Model kompetensi sosial emosional untuk kesiapan sekolah pada anak usia dini (disertasi, tidak dipublikasikan). Surabaya: Universitas Airlangga.

Santrock, J. W. (2013). Life span development (14th ed.). New York: McGraw-Hill.

Sugiyono. (2009). Metode Penelitian Kuantitatif, Kualitatif dan R \& D. Bandung: Alfabeta.

Turner. L.A., \& Johnson, B. (2003). A model of mastery motivation for at-risk preschoolers. $\begin{array}{llll}\text { Journal of Educational } & \text { Psychology, 95(3), }\end{array}$ https:/ / doi.org/https:/ / doi.org/10.1037/0022-0663.95.3.495.

Wang, P., Hwang, A., Liao, H., Chen, P. \& Hsieh, W. (2011). The stability of mastery motivation and its relationship with home environment in infants and toddlers. Infant Behavior $\mathcal{E}$ Development, 34, 434- 442.

Wise, A. M. (2007). Parenting, child mastery motivation, and children's school readiness to learn in Turkey: A structural equation analysis (disertation, unpublished). New York: Syracuse University. 